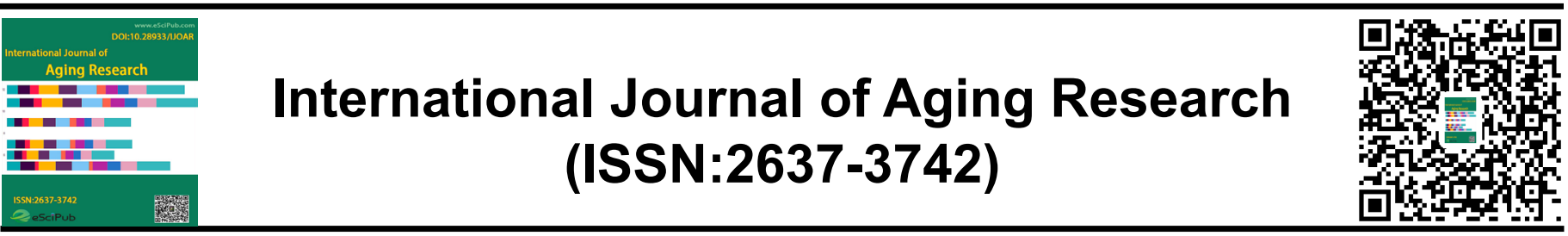

\title{
Position of the Rural Elderly in Familial Decision Making: A Sociological Study
}

\section{Md. Aminul Islam}

Associate Professor, Department of Sociology, University of Rajshahi , Rajshahi- 6205, Bangladesh

\section{ABSTRACT}

Previously the elderly had authoritarian role in familial decision * Correspondence to Author: making process. Now it depends on many associated factors. Dr. Md. Aminul Islam

This study explored the position of the rural elderly in familial de- Associate Professor, Department of cision making process. Mixed approach has been given priority. Sociology, University of Rajshahi, Data have been collected from primary and secondary sources. Rajshahi - 6205, Bangladesh.

The study found that position of elderly in familial decision making process is unsatisfactory. That is, position as head of the family, involvement in buying and selling something, dependency on their sons in receiving treatment, invitation of relatives in difHow to cite this article:

ferent socio-religious occasions, taking part in rural arbitration, Rural Elderly in Familial Decision taking part in resolving familial disputes, influencing in election, Making: A Sociological Study. Intercompelling members to do work according to wishes etc. are not national Journal of Aging Research, satisfactory. This study may help the academicians to conduct $2020,3: 65$ more empirical studies to understand this crucial reality and help the policy makers to take appropriate policy for the welfare of the elderly.

Keywords: Position, Elderly, Family, Decision Making.

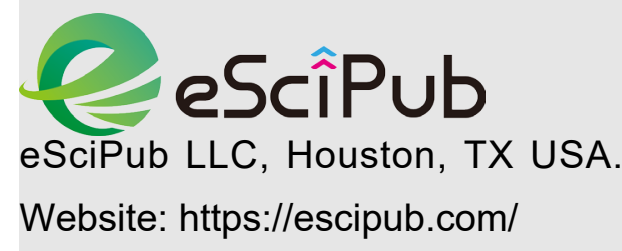


Introduction: The growing number of elderly is the outcome of demographic transition. That is, they are the result of high fertility and mortality to low ones. It has happened due to the reduction in fertility, infant and maternal mortality, infectious and parasitic diseases, as well as improvement in healthcare, improved nutrition, education and income. Demographically, population ageing is a global phenomenon and Bangladesh is also not left untouched by this demographic reality ${ }^{1}$. Social scientists are almost agreed that until the year 1961, both the birth and death rates were high. As a result, the proportion of elderly was at a low level. At present their number is increasing at a significant rate. According to World Health Organization (WHO), the number of senior populations aged 60 years or older is expected to increase at least by $3 \%$ per year. In 2017, the number of senior populations around the world was 963 million people which were $13 \%$ of overall population. Europe got the greatest percentage which is $25 \%$ of European population. The growth in aging population occurs in almost every part of the world except Africa. The aging population in the world which is projected to grow to approximately 1.4 billion people in 2030 and 2 billion in 2050 and can reach 3.1 billion in $2100 .^{2}$ One in four people in the Asia-Pacific region will be 60 years old or older by 2050 . The region is experiencing population ageing at an unprecedented pace, with the number of older persons expected to more than double, from 535 million in 2015 to about 1.3 billion by 2050. ${ }^{3}$ According to information provided by the Bangladesh Bureau of Statistics, around 7.5 percent (12.5 million) of the country's total population constitutes the elderly people while the number is expected to increase sharply and reach around 20 percent (over 40 million) by $2050 .{ }^{4}$ In past, the elderly were treated as the important guardians, mediators and members of the family and society. Now they are considered as the threat to national income, source of increasing dependency, creator of generation gap and social problems in many cases. Moreover, they are, according to Burgess, thrusting into a state of social inactivity that may be termed as role less role. ${ }^{5}$ They observe in their everyday life that the society focuses, advertises, and welcomes the young rather than the old. They have no option but to be treated in many cases as an unattractive, unproductive, unintelligent, unemployable and less important social group. That is, the elderly think that they are in a state of fewer roles and status and they should be abstained from decision making process. In the traditional joint family system, elderly people enjoyed respectable and honorable life. But, the scenario today is almost different. The process of becoming old is taking place at a time when the family pattern is breaking down due to urbanization, migration, economic hardship, declining social values, self-interest, quarrels, maladjustment etc. This changing situation and impact of other disadvantageous socioeconomic conditions are creating problems and unhappiness for many elderly people, especially for the poor families. Due to the size of the population, scarcity of resources, poverty, insufficient health facilities and absence of strong social security, ageing is going to be a major problem for Bangladesh. The role they are playing is sometimes not expected by the member of the family as well as the people of the society. They are playing many imposed roles which are against their status. They are in maximum cases in a position of instrumental head if they are not main income earners. They feel alienation regarding familial decision making process. If their economic condition is not well, they are hardly given priority in various decisions taken in family. Therefore, an attempt has been made in this paper to explore the position of elderly regarding familial decision making process.

Objective of the Study: The objectives of a research summarize what is to be achieved by the study. These should be closely related to the research problem. It must be interrelated, brief and realistic rather than vague and highly 
ambitious. The objectives of the study also explain the purpose of doing, where it will be done, who the subjects are, what will be done in the research etc. However, keeping these in mind the objective of this study has been set to assess the position of elderly in familial decision making process.

Significance of the Study: The aging of population is a pervasive phenomenon across all developing and developed countries of the world. They are the dependent population and losing their role and status in the society. ${ }^{6}$ It is doubtless that the elderly are facing difficult position in our family and society. Though the elderly are highly respected and are still honored in some families, at present they are considered as social problem. The study may give some necessary directions for both academic and policy related benefits. As a contribution to knowledge, this study may focus on micro level investigation to understand the position of elderly in familial decision making process. Besides, the outcome of the study may advocate for taking a national policy for the elderly of Bangladesh. This study also may draw attention to the government as well as the policy makers to solve the problems of the elderly in decision making process and form a policy framework to the welfare of them. Scope and Limitation: No research work is free from inadequacies and limitations. It is really a difficult task for a researcher to collect reliable information on the sensitive and personal issue like their position in decision making process. Besides, Bangladesh is a village-based country. Rural population (\% of total population) in Bangladesh was reported at $63.37 \%$ in 2018, were sourced from the World Bank on April of 2020.7 By studying four villages it may not be possible to get a clear picture of the whole of rural Bangladesh. Besides, the researcher did not consider all the rural elderly in the study area. Only 203 respondents out of 609 have taken as study sample. It may not be representative. Moreover, the overall condition of elderly may not be same to the other parts of the country. The study mainly assessed their position in decision making process. But aging at present is a widened topic of discussion. Polymorphic explanation is associated to this concept. Again, the study has focused on the rural elderly, not urban one. In spite of these limitations, an utmost care taken especially at time of data collection and it was tried to minimize the error in the context of collecting objective data and field working. Ethical issues were also tried to maintain by the researcher during the collection of data.

Methodological Consideration: Methodology means a general orientation about how research is done. ${ }^{8}$ The logic behind adopting certain methodological approaches depends on the nature and purpose of the study. ${ }^{9}$ However, mixed approach that is quantitative and qualitative has been used in this study Qualitative and quantitative data are intimately related to each other. All quantitative data are based upon qualitative judgments; and all qualitative data can be described and manipulated numerically. ${ }^{10}$ No single method ever adequately solves the problem of rival causal factors... multiple methods of observation must be employed. ${ }^{11}$ Quantitative research is based on the measurement of quantity or amount. Qualitative research, on the other hand, is concerned with qualitative phenomenon. ${ }^{12}$ However, an attempt has been made to use several research methods in this study. These are social survey, observation, case study, life history etc. In this study, four villages of Gopalnagar union from Dhunat upazila of Bogra district have been selected randomly. The names of the villages are: Konagaty, Sholiabari, Razarampur and Ariamohan. Although at present about 7.4 percent of our population is elderly, their percentage in these villages is near about 8.0, 7.6, 8.8 and 8.1. ${ }^{13}$ There are various scopes of doing research in these areas. Simple random sampling method has been used for this research to the selection of unions and villages. In this respect lottery system has been adopted to choose the union and villages. The reason is, in this method, each individual has an equal 
probability of being selected from the population, ensuring that the sample will be representative of the population. On the other hand, the district and upazila have been selected purposively. The reason behind this purposive selection is, at present the percentage of the elderly in Bangladesh is about 7.4, the average percentage of elderly in Bogra district is about 7.9 and in Dhunat upazila it is near about 8.6. ${ }^{14}$ The same socio-economic, cultural and demographic situations, significant proportion of the elderly, characteristics of village life encouraged the researcher to select this upazila purposively. The villages have been surveyed to find out the elderly. From the total elderly (that is from 609), 203 have been selected as study sample. 203 respondents have also been used for scheduled questionnaire survey. Ten cases have also been studied. Required qualitative and quantitative data have been collected through questionnaire which includes both openended and close- ended questions as primary data source. Secondary data have been collected through document analysis. Collected data in this study have been processed and analyzed with the help of computer. SPSS has also been used.

Results and Discussion: Decision making process of the elderly in family is a complicated work. Various factors are closely associated with it. It has relationship with headship, income earner, possession of wealth in the family. It controls and directs the socio-economic condition, socialization process, political, religious and cultural processes in the society. Here, it has tried to shown on the basis of head of the family of the elderly, principal income earner, decision maker on spending income, decision maker of building and repairing houses, decision maker of receiving treatment, decision maker of educating children, seeking permission of going outside from home, etc. It is also mentionable here that if the role and status is decreased, the elderly becomes dependent on the family and society. If the elderly become dependent members, generally they become non-income earner, non head and non-decision maker in the family. That is, status as head of the family associated to authority and prestige not by the reason of age alone; it is determined by several factors, including education, occupation, marital status, health condition, resources, etc. The elderly who are not capable or who have less resources are less consulted and informed about the familial matters including arranging marriage, purchasing valuable goods, selling property, building and repairing houses, educating children and receiving treatment. It is also found that the position of the male elderly in terms of controlling over property such as economic wealth, land, sons, and daughters is better than that of the female elderly. The involvement of the male elderly in familial decision is higher than the female one.

Table 1: Age status of the elderly

\begin{tabular}{|c|c|c|c|c|c|c|}
\hline Age categories & Frequency (Male) & $\%$ & Frequency (Female) & $\%$ & Total number & $\%$ \\
\hline $60-65$ & 46 & 22.7 & 72 & 35.5 & 118 & 58.1 \\
\hline $65-70$ & 15 & 7.4 & 14 & 6.9 & 29 & 14.3 \\
\hline $70-75$ & 24 & 11.8 & 11 & 5.4 & 35 & 17.2 \\
\hline $75-80$ & 5 & 2.4 & 3 & 1.5 & 8 & 3.9 \\
\hline $80-85$ & 3 & 1.5 & 4 & 1.9 & 7 & 3.4 \\
\hline $85-90$ & 3 & 1.5 & 3 & 1.5 & 6 & 3.0 \\
\hline Total & 96 & 47.3 & 107 & 52.7 & 203 & 100.0 \\
\hline
\end{tabular}


The age categories of the respondents show that (60-75) represents the highest concentration of elderly considering age while ( 80 and above that is old-old) are the lowest. That is, most of the respondents are in the age group of 60-75. The interesting fact is that the female elderly are highest in the age group (60-65) than the male one. In this situation it can be said that the female of Bangladesh, especially in our rural settings, become elderly faster than the male elderly. After all, the percentage of young old is highest in the population structure in the research area.

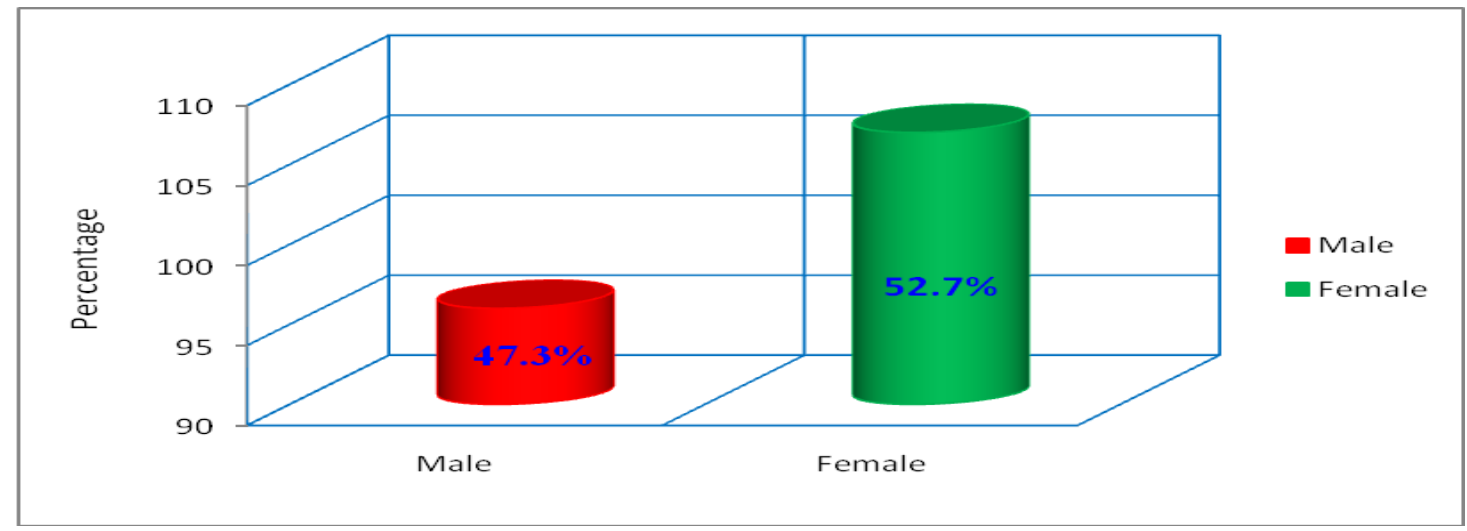

Figure 1: Sex status of the elderly

This figure indicates that among the total elderly the percentage of male elderly is 47.3 whereas the female elderly is 52.7 . So, it is easily understandable that the percentage of female is higher than the male elderly in the study area.

Table 2: Level of education of the elderly

\begin{tabular}{|c|c|c|c|c|c|c|}
\hline Level of Education & Frequency of Male & $\%$ & Frequency of Female & $\%$ & Total & $\%$ \\
\hline Nil & 72 & 35.5 & 85 & 41.8 & 157 & 77.3 \\
\hline Signature ability & 12 & 5.9 & 13 & 6.5 & 25 & 12.3 \\
\hline Primary & 5 & 2.5 & 6 & 2.9 & 11 & 5.4 \\
\hline Secondary & 5 & 2.5 & 3 & 1.5 & 8 & 4.0 \\
\hline Higher secondary & 1 & 0.5 & 0 & 0 & 1 & 0.5 \\
\hline Graduate & 1 & 0.5 & 0 & 0 & 1 & 0.5 \\
\hline Total & 96 & 47.4 & 107 & 52.6 & 203 & 100.0 \\
\hline
\end{tabular}

From the table it is easily understandable that about 77.3 percent elderly, both male and female do not know how to write and read. The percentage of male is 35.5 and female is 41.8 . Here, merely, 12.5 percent elderly males and 12.1 percent elderly females have no formal education. But they can sign only. Again, the ratio of higher education is very poor and limited among them. About 4.0 percent crossed the level of secondary examination and 0.5 percent merely passed higher secondary examination. Only 0.5 percent has crossed the level of graduation among the elderly. So, it can be said that the educational status of the rural elderly in Bangladesh is very low. About 12.3 percent including 5.9 percent male and 6.5 percent female acquired the ability of sign as it is necessary for some purposes. 
Table 3: Head of the family of the elderly

\begin{tabular}{|c|c|c|c|c|c|c|c|c|c|c|c|c|c|}
\hline \multicolumn{2}{|c|}{$\begin{array}{l}\text { Age Group of the } \\
\text { respondents }\end{array}$} & Self & $\%$ & Son & $\%$ & $\frac{\grave{d}}{\frac{ \pm}{5}}$ & $\%$ & 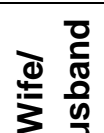 & $\%$ & Others & $\%$ & Total & $\%$ \\
\hline \multirow{7}{*}{ Male } & $60-65$ & 39 & 40.6 & 4 & 4.2 & - & - & 3 & 3.1 & - & - & 46 & 47.9 \\
\hline & $65-70$ & 15 & 15.6 & - & - & - & - & - & - & - & - & 15 & 15.6 \\
\hline & $70-75$ & 23 & 24.0 & 1 & 1.0 & - & - & - & - & - & - & 24 & 25.0 \\
\hline & $75-80$ & 3 & 3.1 & 2 & 2.1 & - & - & - & - & - & - & 5 & 5.2 \\
\hline & $80-85$ & 3 & 3.1 & - & - & - & - & - & - & - & - & 3 & 3.1 \\
\hline & $85-90$ & 3 & 3.1 & - & - & - & - & - & - & - & - & 3 & 3.1 \\
\hline & Total & 86 & 89.6 & 7 & 7.3 & - & - & 3 & 3.1 & - & - & 96 & 100.0 \\
\hline \multirow{8}{*}{ Female } & $60-65$ & 20 & 18.7 & 32 & 29.9 & - & - & 16 & 15.0 & 4 & 3.7 & 72 & 67.3 \\
\hline & $65-70$ & 4 & 3.7 & 6 & 5.6 & 1 & 0.9 & 3 & 2.8 & - & - & 14 & 13.1 \\
\hline & $70-75$ & 2 & 1.9 & 5 & 4.7 & - & - & 3 & 2.8 & 1 & .9 & 11 & 10.3 \\
\hline & $75-80$ & - & - & 2 & 1.9 & 1 & 0.9 & - & - & - & - & 3 & 2.8 \\
\hline & $80-85$ & - & - & 4 & 2.8 & - & - & - & - & - & - & 3 & 2.8 \\
\hline & $85-90$ & 1 & 0.9 & 2 & 2.8 & - & - & - & - & - & - & 4 & 3.7 \\
\hline & Total & 27 & 25.2 & 51 & 47.7 & 2 & 1.9 & 22 & 20.6 & 5 & 4.7 & 107 & 100.0 \\
\hline & G.total & 113 & 55.7 & 58 & 28.6 & 2 & 1.0 & 25 & 11.5 & 5 & 2.5 & 203 & 100.0 \\
\hline
\end{tabular}

Head of the family in rural Bangladesh is considered as the central figure of enjoying the highest social status. From the table it is understandable that considering head, the percentage of the male elderly is 89.6. Among them 40.6 percent is $60-65$ age categories, about 15.6 percent is $65-70$ and 24.0 percent is in 70-75 age categories. The rest of the percentage of the male elderly belongs to the above eighty years which is negligible percent. So, it can be said that, in case of head of the family, the young elderly have satisfactory position than the young, old or the old elderly. On the other hand, the percentage of the female elderly in this respect is about 25.2 percent from which 18.7 percent belongs to $60-65$ age.

In traditional societies, older people were often accorded a great deal of respect. Involvement in decision making process in family is the indicator of social status of the elderly and also the element of empowerment in family. In rural arena of our country the elderly were simultaneously income earners and decision makers. If they would not be income earners, they were still decision makers because, the familial tie and authority, norms and values, and custom and tradition were high for obeying the decision of the elderly in the family and society whether they were income earners or not. Now it is seen that the main income earners in maximum cases are involved in this matter. From this study it is easily observed that 38.4 elderly are the principal income earners and decision makers. The position of son in this point is about 32.5 percent. Though 32.5 percent sons are simultaneously income earners and decision makers, 12.3 percent elderly are decision makers though their sons are principal income earners. According to our tradition, the elderly are supposed to be decision makers. So, it indicates a changing situation in our social norms and values. 
Md. Aminul Islam, IJOAR, 2020 3:65

Table 4: Principal income earner and decision maker of the family of the elderly

\begin{tabular}{|c|c|c|c|c|c|c|c|c|c|c|c|c|c|c|}
\hline \multirow[b]{2}{*}{$\begin{array}{l}\text { Principal } \\
\text { income } \\
\text { earner }\end{array}$} & \multicolumn{12}{|c|}{ Principal decision maker of the family } & \multirow[b]{2}{*}{$\begin{array}{l}\bar{\pi} \\
\stackrel{\sigma}{0} \\
\end{array}$} & \multirow[b]{2}{*}{$\%$} \\
\hline & ¿े & $\curvearrowright$ & $\begin{array}{l}\frac{\omega}{D} \\
\stackrel{\infty}{0}\end{array}$ & ○ & $\stackrel{\oplus}{\stackrel{0}{3}}$ & $\overbrace{}^{\circ}$ & 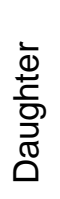 & $\circ$ & 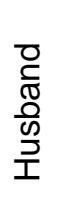 & $\circ$ & $\begin{array}{l}\bar{\Phi} \\
\stackrel{ \pm}{ \pm}\end{array}$ & ஃ & & \\
\hline Son & 66 & $\begin{array}{c}32 . \\
5\end{array}$ & 25 & 12.3 & 2 & 0.9 & - & - & 1 & 0.5 & 1 & 0.5 & 95 & 46.8 \\
\hline Son's wife & - & - & 1 & 0.5 & - & - & - & - & - & - & - & - & 1 & 0.5 \\
\hline Self & 3 & 1.5 & 78 & 38.4 & - & - & - & - & - & - & - & - & 81 & 39.9 \\
\hline Daughter & - & - & - & - & - & - & 2 & 0.9 & - & - & - & - & 2 & 1.0 \\
\hline Husband & - & - & 2 & 0.9 & - & - & - & - & 15 & 7.4 & - & - & 17 & 8.4 \\
\hline Other & - & - & - & - & - & - & 2 & 0.9 & 1 & 0.5 & 4 & 1.9 & 7 & 3.4 \\
\hline Total & 69 & 34 & 106 & 52.2 & 2 & 0.9 & 4 & 1.8 & 17 & 8.4 & 5 & 2.4 & 203 & 100 \\
\hline
\end{tabular}

Table 5: Principal income earners and decision makers of spending earned income

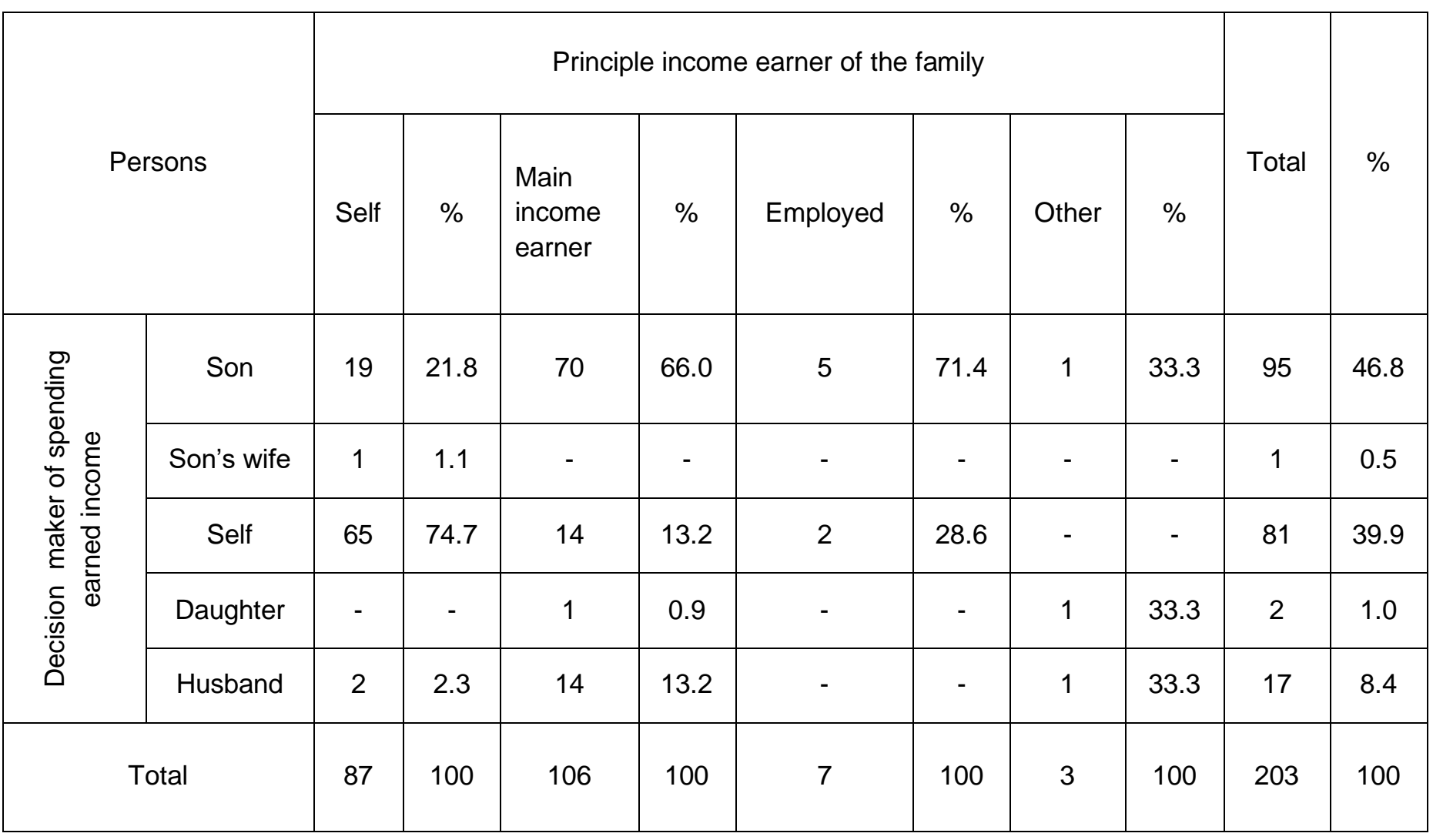

About 39.9 percent elderly are the principal and 21.8 percent of them can take decision of income earners, 74.7 percent can take decision spending their income. So, the decision of of spending their income. Near about 46.8 spending earned income is gradually vested on percent sons are the principal income earners sons of the family. 
Table 6: Decision making in buying and selling various items in the family of the elderly

\begin{tabular}{|c|c|c|}
\hline Decision Making & Frequency & Percent \\
\hline Son & 66 & 32.5 \\
\hline Self & 102 & 50.2 \\
\hline Wife & 9 & 4.4 \\
\hline Daughter & 4 & 2.0 \\
\hline Husband & 21 & 10.3 \\
\hline Other & 1 & 0.5 \\
\hline Total & 203 & 100.0 \\
\hline
\end{tabular}

The table represents that 50.2 percent respondents are still involved in buying and selling necessary things in the family. On the other hand, the percentage of sons in this case is about 32.5 percent. About 10.3 percent in this respect is husband, that is, the female elderly who have husbands. The decision is taken by them in this regard. Merely 2.0 percent daughters are able to take part in doing these activities.

Table 7: Decision making in building and repairing in the family of the elderly

\begin{tabular}{|c|c|c|}
\hline Decision Making & Frequency & Percent \\
\hline Son & 73 & 36.0 \\
\hline Self & 97 & 47.8 \\
\hline Wife & 6 & 3.0 \\
\hline Daughter & 4 & 2.0 \\
\hline Husband & 22 & 10.8 \\
\hline Other & 1 & 0.5 \\
\hline Total & 203 & 100.0 \\
\hline
\end{tabular}

Decision making in building and repairing dwelling houses is also important for enjoying role and status in the rural society of Bangladesh. Traditionally the elderly have mentality that their family members will give them importance in this matter. From the table it can be understood that 47.8 percent elderly is still active in this state of affaire. The dependency on sons in this matter is about 36.0 percent. The percentage of the husbands of the female elderly in this issue is also countable, no doubt.

It is found that, 45.8 percent elderly can take decision for receiving treatment in the family and
37.4 percent depend on their sons. In the case of the female elderly, 11.8 percent depend on their husbands.

It is apparent from the table that nearly 54.7 percent elderly replied that they are to seek permission and 45.3 percent of them opined that they are not taken permission. The condition of female elderly is not good than male one. They were asked why they seek permission from family members as well as why they are not seek permission. They replied that they are to perform many tasks in the family for these reasons they are to seek permission from their family members. 
Table 8: Decision makers for receiving treatment in the family

\begin{tabular}{|c|c|c|}
\hline Decision Making & Frequency & Percent \\
\hline Son & 76 & 37.4 \\
\hline Self & 93 & 45.8 \\
\hline Wife & 6 & 3.0 \\
\hline Daughter & 3 & 1.5 \\
\hline Husband & 24 & 11.8 \\
\hline Other & 1 & 0.5 \\
\hline Total & 203 & 100.0 \\
\hline
\end{tabular}

Table 9: Seeking permission for going outside from home

\begin{tabular}{|c|c|c|c|c|c|c|}
\hline \multirow{2}{*}{ Opinion } & \multicolumn{4}{|c|}{ Sex of the respondent } & \multirow{2}{*}{ Total } & \multirow{2}{*}{$\%$} \\
\hline & Male & $\%$ & Female & $\%$ & & \\
\hline Yes & 33 & 16.25 & 78 & 38.4 & 111 & 54.7 \\
\hline No & 63 & 31.03 & 29 & 14.3 & 92 & 45.3 \\
\hline Total & 96 & 47.23 & 107 & 52.7 & 203 & 100.0 \\
\hline
\end{tabular}

Table10: Position and nature of acceptance of the decision of the elderly in the family

\begin{tabular}{|c|c|c|c|c|c|c|c|c|}
\hline \multirow{2}{*}{ Position in the family } & \multicolumn{5}{|c|}{ Nature of accepting decisions by the family members } & \multirow{2}{*}{ Total } & $\%$ \\
\cline { 2 - 8 } & Properly & $\%$ & Conventionally & $\%$ & Don't accept & $\%$ & & \\
\hline Head of family & 75 & 36.9 & 22 & 10.8 & 3 & 1.5 & 100 & 49.3 \\
\hline Elderly & 24 & 11.8 & 22 & 10.8 & 7 & 3.4 & 53 & 26.1 \\
\hline Dependent & 13 & 6.4 & 21 & 10.3 & 8 & 4.0 & 42 & 20.7 \\
\hline Only Member & 1 & 0.5 & 5 & 2.5 & 2 & 0.9 & 8 & 3.9 \\
\hline Total & 113 & 55.6 & 70 & 34.4 & 20 & 9.8 & 203 & 100 \\
\hline
\end{tabular}

The table shows that when 49.3 percent elderly enjoy their status as the head of the family, their decision is about 36.9 percent accepted properly, 10.8 percent conventionally and 1.5 percent of their decision is not accepted by the family members. When their status is elderly in the family 11.8 percent decision of them is accepted properly, 10.8 percent conventionally and 3.4 percent is not accepted. If they are considered as the only family members, their position in the family is vulnerable. It is noticeable that if the position of elderly in the family is head, their decision is given priority significantly. On the other hand, if the position of the elderly in the family is only elderly, their decision in the family is not given priority properly. 


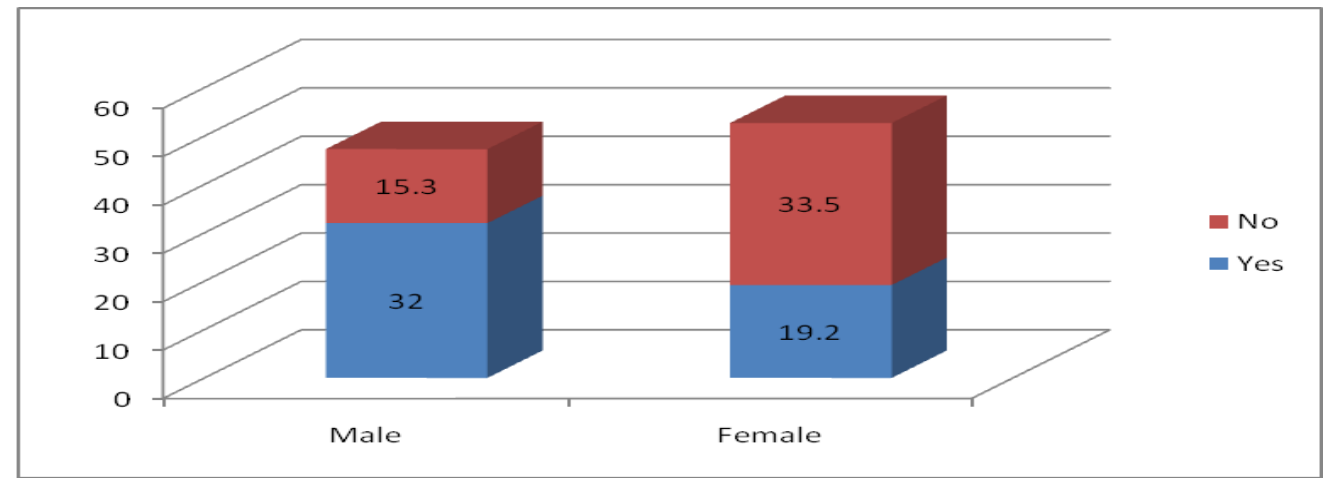

Figure 2: Compelling family members to do work according to the desire of the elderly

The figure above hints the ability to compel the members of the family to do work according to the wishes of the elderly in the rural society. It is obvious from the graph that near about fifty percent including 32.0 percent male and 19.2 percent female can compel the members to do work according to their wishes. On the other hand, about 48.8 percent elderly including 15.3 percent male and 33.5 percent female cannot do this.

Table 11: If the elderly can invite relatives on different socio- religious occasions

\begin{tabular}{|c|c|c|}
\hline Response & Frequency & Percent \\
\hline Yes & 123 & 60.6 \\
\hline No & 80 & 39.4 \\
\hline Total & 203 & 100.0 \\
\hline
\end{tabular}

The data in the above table points out that about 60.6 percent elderly can invite their relatives in different socio religious occasions. On the other hand, 39.4 percent elderly cannot do this due to lack of economic ability. So, it is clear from the explanation that in spite of having inclination significant number of elderly in our rural society cannot do this mainly for economic hardship.

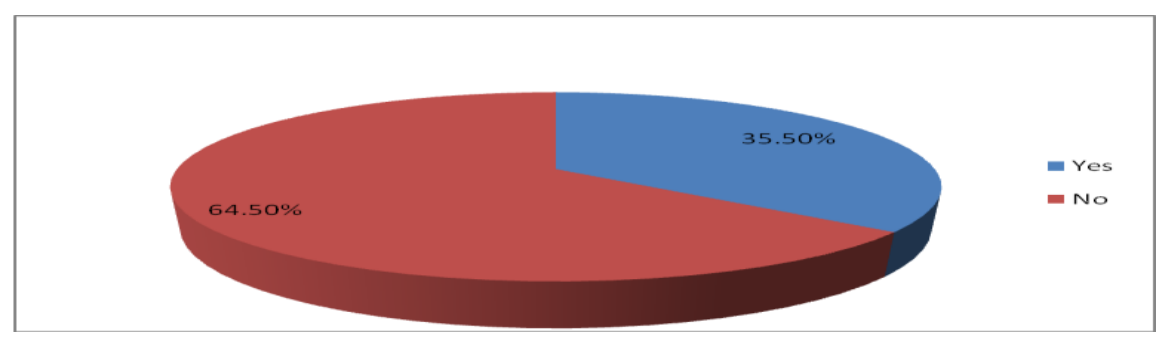

Figure 3: Participation of elderly in rural arbitration

Taking part in rural arbitration is also the symbol of enjoying role and status of the elderly. But it depends on the economic condition, educational qualities or level of education, previous position of occupation, access to urban society, powerful persons among the relatives, political attachment with the political parties, physical ability and ascribed qualities of elderly in rural settings. Those who have highest position in these sectors are able to take part in rural arbitration and the rural people also fear to them and abide by their decisions. The table shows that 35.5 percent elderly can take part in this matter. The pathetic fact is that, 64.5 percent elderly cannot take part in rural arbitration. 
Table 12: If the elderly have congenial familial relationship with family members

\begin{tabular}{|c|c|c|c|c|c|c|}
\hline \multirow{2}{*}{$\begin{array}{l}\text { Sex of the } \\
\text { respondent }\end{array}$} & \multicolumn{4}{|c|}{ Response } & \multirow{2}{*}{ Total } & \multirow{2}{*}{$\%$} \\
\hline & Yes & $\%$ & No & $\%$ & & \\
\hline Male & 84 & 41.4 & 12 & 5.91 & 96 & 47.3 \\
\hline Female & 92 & 45.3 & 15 & 7.39 & 107 & 52.7 \\
\hline Total & 176 & 86.7 & 27 & 13.3 & 203 & 100.0 \\
\hline
\end{tabular}

The question was asked to the elderly whether their familial relationship is satisfactory or not for enjoying status. About 41.4 percent male and 45.3 percent female replied positively. On the other hand 5.91 percent male and 7.39 percent female replied negatively. Though family is the best place in our society for the care of the elderly, they think that familial relationship is not congenial for the enjoyment of role and status.

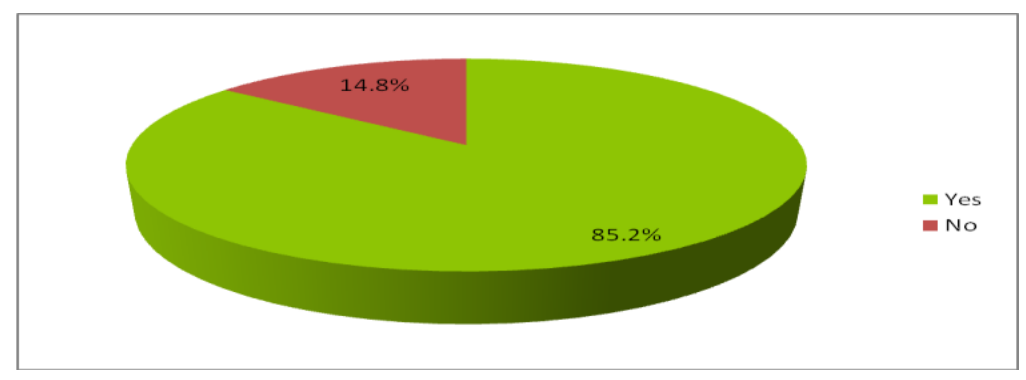

Figure 4: Showing respect to elderly for religious activities by the family members

It is almost a normal matter that the elderly will be respected in the family because of having their stock knowledge on religion. From the table above it is understandable that 85 percent show respect and 14.8 percent do not.

Table 13: If the family members influence the elderly at time of election

\begin{tabular}{|c|c|c|c|c|c|c|}
\hline \multirow{2}{*}{ Sex } & \multicolumn{4}{|c|}{ Influence the elderly at time of election } & \multirow{2}{*}{ Total } & \multirow{2}{*}{$\%$} \\
\hline & Yes & $\%$ & No & $\%$ & & \\
\hline Male & 36 & 17.7 & 60 & 29.6 & 96 & 47.3 \\
\hline Female & 54 & 26.6 & 53 & 26.1 & 107 & 52.7 \\
\hline Total & 90 & 44.3 & 113 & 55.7 & 203 & 100 \\
\hline
\end{tabular}

The data in the above table illustrates that about 44.3 percent elderly including 17.7 percent male and 26.6 percent female replied that the family members influence them before election. Again, 55.7 percent elderly including 29.9 percent male and 26.1 percent female mentioned that the family members do not influence them at time of election. Once upon a time the elderly were the counselors and advisors. Now they are influenced by the family members significantly. 
Table 14: If the elderly take part in family disputes

\begin{tabular}{|c|c|c|c|c|c|c|}
\hline \multirow{2}{*}{ Age Group } & \multicolumn{7}{|c|}{ Response } \\
\cline { 2 - 7 } & Yes & $\%$ & No & $\%$ & Total & $\%$ \\
\hline $60-65$ & 97 & 47.8 & 21 & 10.3 & 118 & 58.1 \\
\hline $65-70$ & 23 & 11.3 & 6 & 3.0 & 29 & 14.2 \\
\hline $70-75$ & 33 & 16.3 & 2 & 1.0 & 35 & 17.3 \\
\hline $75-80$ & 5 & 2.5 & 3 & 1.5 & 8 & 4.0 \\
\hline $80-85$ & 6 & 3.0 & 1 & 0.5 & 7 & 2.9 \\
\hline $85-90$ & 4 & 2.0 & 2 & 1.0 & 6 & 3.4 \\
\hline Total & 161 & 82.8 & 42 & 17.2 & 203 & 100 \\
\hline
\end{tabular}

Taking part in resolution of familial disputes is the symbol of enjoying role and status of elderly. The table shows that 82.8 percent elderly can take part in this matter of which 47.8 percent elderly belongs to age group of 60-65.

Conclusion: The analysis above represents that the position of elderly in familial decision making is not so satisfactory in all states of familial affairs as per expectation. The percentage of headship, principal income earners, decision making in buying and selling something in the family, acceptance of decision by the family members of the elderly, dependency on their sons regarding decision making in receiving treatment, inviting relatives in different socio religious occasions, compelling the members to do work according to their wishes, taking part in resolving familial disputes, showing respect to religious activities in family, receiving influence before election, taking part in rural arbitration etc are not so satisfactory. So, in some cases seemingly they have well position but as an elderly and merely family member their status is not satisfactory in the family. Question was also asked to the respondents whether the elderly could take part in these decisions previously or not. About 67.0 percent of the elderly replied positively whereas 33.0 percent replied that they have no idea about it. Kofi Anan, the secretary general of United Nations said that "Trees grow stronger over the years, rivers wider. Likewise with age, human beings gain immeasurable depth and breadth of experience and wisdom. That is why older persons should not only be respected and revered; they should be utilized as the rich source to society that they are". ${ }^{15}$ Further more and more empirical study should be conducted covering entire rural society of Bangladesh to portray their condition.

Acknowledgment: The study was funded by Social Science Research Council, Planning Division, Ministry of Planning, The People's Republic of Bangladesh. So, I am gratefully acknowledging their contribution to this work. Because the economic support provided by this organization helped me a lot to the completion of this task successfully.

\section{References}

1. K.M Mustafizur,Rahman, Present Social Context and Elderly Population in Bangladesh (Dhaka:Unnayan Onneshan, 2010).

2. MICE Intelligence Center, "The Aging Population and the Global Trend," Accessed February 15, 2020,

https://intelligence.businesseventsthailand.com/e $\mathrm{n}$ /insight/aging-trends-01.

3. United Nations, "Addressing the Challenges of Population Ageing in Asia and the Pacific: Implementation of the Madrid International Plan of Action on Aging,"Accessed February 15, 2020,https://www.unescap.org/sites/default/files/ publications/Addressing\%20the\%20Challenges\% 20of\%20Population\%20Ageing\%20in\%20Asia\% 20and\%20the\%20Pacific.pdf. 
4. Inter Press Service, "Bangladesh faces a challenge to ensure welfare of its aging population," Accessed February 15, 2020, http://www.ipsnews.net/2019/02/bangladeshfaces-challenge-ensure-welfare-agingpopulation/ .

5. Earnest W. Burgess ed, Aging in Western Societies (Chicago: University of Chicago Press, 1960).

6. S. Mishra ,Problem and Social Adjustment in Old Age: A Sociological Analysis (New Delhi,Gian Publishing House, 1989).

7. Trading Economics, "Bangladesh-Rural Population," Accessed April 1, 2020, https://tradingeconomics.com/bangladesh/ruralpopulation-percent-of-total-population-wbdata.html.

8. Amir B Marvasti, Qualitative Research in Sociology; An Introduction (New Delhi: Sage Publication, 2004).

9. Pauline V. Young, Scientific Social Survey and Research, 3rd ed. (Bombay: Asia Publishing House, 1966)
10. M.K .William Trochim, Research Methods (New Delhi: Biztantra, 2009).

11. M. Q. Patton, Qualitative Evaluation and Research Methods, 2nd ed, (London: Sage Publications, 1990)

12. C. R. Kothari, Research Methodology: Methods and Techniques (New Delhi: New Age International Publishers, 2009).

13. Bangladesh Bureau of Statistics (BBS) "Community Report on Bogra Zila: Population and Housing Census 2011", Ministry of Planning, Dhaka: Government of the People's Republic of Bangladesh, 2012.

14. Bangladesh Bureau of Statistics (BBS), "Population and Housing Census 2011: Community Report- Bogra Zila," Dhaka: Statistics and Informative Division, Ministry of Planning, 2012.

15. Kofi Anan, "Positive Ageing - Older, Wiser, Happier," Accessed March 31, 2020 http://www.whenat60.com/positive-ageing-olderwiser-happier/ 